\title{
Social-ecological memory in an autobiographical novel: ecoliteracy, place attachment, and identity related to the Korean traditional village landscape
}

\author{
$\underline{G o W o n ~ K i m}^{1}, \underline{\text { Rahul Teku Vaswani }}^{2}$ and $\underline{\text { Dowon Lee }}^{3}$
}

\begin{abstract}
Our study discusses how literature, in particular an autobiographical novel, can be approached as a valuable reservoir of social-ecological memory (SEM). Through our analysis of acclaimed Korean writer Park Wan-suh's autobiographical novel Who Ate Up All the Shinga?, we discuss how an individual (the author) manifests ecoliteracy, place attachment, and identity in relation to Korea's traditional village landscape that can serve as a suitable setting for understanding Korea's local social-ecological contexts. We find a rich account of knowledge and practices related to living and ecological components, resource and landscape management systems, social institutions, and worldviews. The author's descriptions of her native village landscape show the role of village resource and landscape management practices in enhancing local biodiversity and developing ecoliteracy in relation to indigenous ecosystemlike concepts. In addition, several social capitals are mentioned as key to sustaining the village community. The author's knowledge of local plants is the result of her childhood experiences in nature, and her place attachment is tightly linked with her worldview that is cultivated through intricate human-nature relationships within the Korean traditional village landscape. Furthermore, the novel contributes to comprehending resilience thinking by providing a narrative of social changes and interactions between humans and nature. Thus, SEM retained in literature can facilitate a meaningful understanding of social-ecological contexts in a given socialecological system. Our study therefore suggests new functions of autobiographical memory in literary work for delivering SEM, and informs the study of SEM across the fields of humanities, social sciences, and natural resources management.
\end{abstract}

Key Words: autobiographical memory; ecoliteracy; Korea's traditional village landscape; literature; place attachment; social-ecological memory; spatial identity; traditional ecological knowledge

\section{INTRODUCTION}

In a social-ecological system (SES), sustainability refers to maintaining the essential elements for renewal and reorganization when the system's structure or function is affected by a disturbance (Walker et al. 2002). Similarly, resilience, in the systems approach, refers to the SES's capacity to absorb disturbance and reorganize, through self-organization or learning and adaptation, so as to maintain the SES's identity (Carpenter et al. 2001, Cumming 2011a, Walker and Salt 2012). In this regard, researchers of SES have increasingly focused their attention to the factors that enhance resilience and adaptive capacity of an SES in the face of change and perturbations (e.g., Olsson et al. 2004, Berkes and Seixas 2005, Folke et al. 2005, Folke 2006, Ahern 2013, Ruiz-Mallén and Corbera 2013). Recent studies show that memory is important for social-ecological resilience; it is a resource for renewal, reorganization, and innovation when an SES experiences disturbance or crisis (Folke et al. 2003, DavidsonHunt and Berkes 2003, Folke et al. 2005, Barthel et al. 2010, Nykvist and von Heland 2014).

Sociologists since the early 20 th century have examined memory as a process that operates within certain social institutions (Olick and Robbins 1998) and have presented it in two primary frameworks: autobiographical memory and historical memory (Halbwachs 1992, Barthel et al. 2010). Autobiographical memory refers to an individual's narratives of identity based on personal experiences, whereas historical memory refers to the knowledge and information stored in institutions, physical forms and places, and documents (Halbwachs 1992, Barthel et al. 2010).

Most of the literature on memory, however, is the result of nonparadigmatic and transdisciplinary perspectives (Olick and Robbins 1998), and memory has functions in various fields.
Recent SES studies have examined memory from social-ecological perspectives, thus framing it as social-ecological memory (SEM). An early extensive review of memory from SES perspectives was done by Berkes et al. (2003), however, the study by Barthel et al. (2010) was perhaps the first that explored specific evidence of SEM in a real system and defined it as the memory of people who participate in ecosystem management.

We further discuss SEM, particularly suggesting that SEM consists of three pillars: person, practice, and place in relation to ecosystem management. Furthermore, we suggest that works of art, such as literary works and landscape paintings, can reflect the SEM of the artists, which provide valuable information for a social-ecological understanding of a given SES as presented in the art. The analytical use of literature and the arts is already becoming important for understanding the influence of cultural factors for sustainability (Brocchi 2010). In this vein, our study explores an autobiographical account to find its role as a valuable reservoir of SEM and discusses its usefulness for understanding the social-ecological contexts of a given SES.

\section{SOCIAL-ECOLOGICAL MEMORY AS A PERSON- PRACTICE-PLACE COMPLEX}

Researchers of SES discuss SEM as either the combination of ecological memory and social memory (Morehouse et al. 2008, Cumming 2011b), or the combined knowledge, practices, and experiences of ecosystem management (Berkes et al. 2003, Barthel et al. 2010, Nykvist and von Heland 2014). Although social memory is understood to be socially shaped and constructed (Halbwachs 1992), thereby highlighting the social dimensions in which knowledge is transmitted in time (Swidler and Arditi 1994), SEM studies focus on the social-ecological dimensions of memory, particularly in relation to ecosystem management

${ }^{1}$ Asian Institute for Energy, Environment and Sustainability, Seoul National University, ${ }^{2}$ United Nations Economic and Social Commission for Asia and the Pacific, Bangkok, Thailand, ${ }^{3}$ Graduate School of Environmental Studies, Seoul National University 
practices (Barthel et al. 2010). Studies of SEM may include the attributes of practices (or experiences) of ecosystem management, and the place where the practices occur. In our study, we adhere to this understanding of SEM and suggest it as a person-practice-place complex. The dynamic feedback among these three pillars manifests as ecoliteracy, place attachment, and the related identity of a place (Fig. 1).

Fig. 1. A conceptual framework for social-ecological memory as a person-practice-place complex with ecoliteracy, place attachment, and identity as emergent outcomes of their complex linkages.

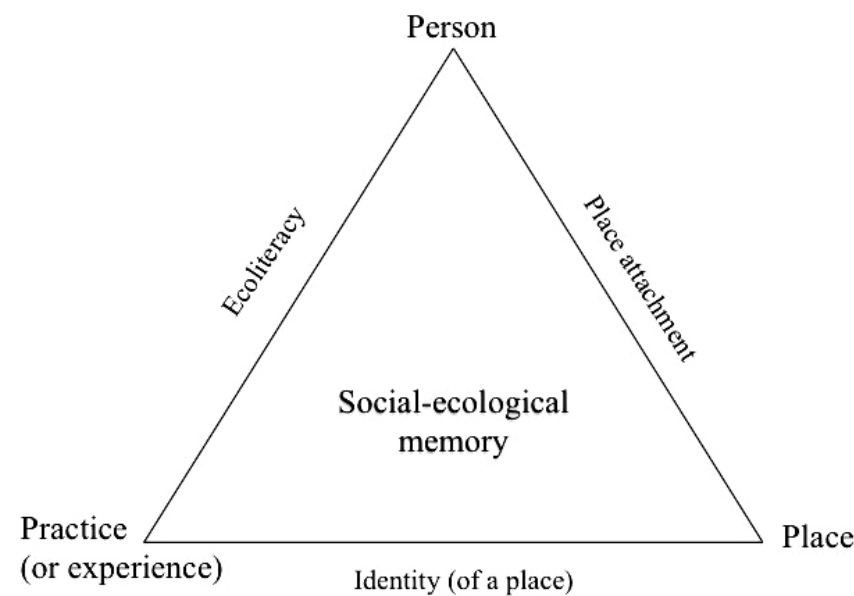

Here "person" refers to the individual as the main agent of memory, and to individuals who influence or share practices with the main agent. In an SES, individuals are regarded as potential stewards of their communities (Chapin et al. 2009). An individual being is also an actor in social-ecological processes, and is regarded as the smallest scale or unit in the analysis of SES resilience (Cumming et al. 2015). An individual's knowledge, worldview, social-ecological interactions, and approaches to ecosystem management result from the individual's experiences; experiences inform perceptions that define the individual's attitudes and behaviors; and depending on the nature of social feedback, the individual's actions can be either reinforced or corrected. In turn, individuals, through their ecological knowledge, cognitive skills, and behaviors, which are collectively termed as ecoliteracy (Capra 1996), can impact ecosystem patterns and processes (McBride et al. 2013).

To refer to a person's ecological competence, we purposely choose ecoliteracy over environmental literacy and ecological literacy, because the concept of ecoliteracy includes spiritual and holistic components, thereby suggesting a character with well-rounded abilities of head, heart, hands, and spirit (McBride et al. 2013). We also draw from Lam (2014) and Pilgrim et al. (2007) in defining ecoliteracy as the ability to identify names, uses, and related stories of living organisms and natural phenomena within their socialecological systems, perpetuated by oral transfer of traditional ecological knowledge (TEK). Given that TEK is defined as a knowledge-practice-belief complex (Berkes 2009), a person possessing TEK may also be considered an ecoliterate person. Studies on TEK have discussed how the knowledge systems of local and indigenous groups contribute to building resilience and adaptive capacity in an SES, particularly at the community level (e.g., Berkes et al. 2000, Berkes and Seixas 2005, Berkes and Turner 2006, Berkes 2008, 2009).

Many traditional communities, particularly resource-dependent communities, have sustained themselves through their ecoliterate members (Pilgrim et al. 2007). In the modern context of industrialization and globalization, ecoliterate leaders guide their communities to premeditate and withstand undesirable socialecological impacts, with their TEK and holistic beliefs related to their SES. A well-known example is of Sarah James, a Native Alaskan who leads her community's efforts on protecting the Porcupine caribou habitat and the sustenance of indigenous communities dependent on the caribou, by resisting the moves of the oil industry of the United States in Alaska (Goleman et al. 2012).

A person's ecoliteracy is developed or manifested though "practice" in a real SES, which refers to the past or present habitual activities and experiences in relation to ecosystem management. Barthel et al. (2010), for example, discuss gardening activities in allotment gardens in the Stockholm urban area, Sweden as an example of such an ecosystem management practice. Practice is the result of long-term interaction between person and place, thus incorporating cultural, historical, and spiritual aspects. Although some ecologists are skeptical of indigenous and local knowledge and practice, much of the current scientific knowledge on biology has also undergone verification in apprenticeship with local knowledge holders (Berkes 2008). It is in this sense that various SES studies acknowledge the importance of SEM without explicitly referring to "socialecological memory" and instead focus on the alternative knowledge systems related to local ecosystem stewardship practices.

"Place" is the physical site in which a person has experienced and learned through practice about ecosystem management, complex systems thinking, and the link between nature and humans. Barthel et al. (2010) label these physical sites in urban areas as "pockets of social-ecological memory." Physical sites may vary in spatial-temporal scale, but all have a "spatial identity" that is influenced and shaped by endogenous and exogenous variables within the SES; similarly "place identity" is directly established by people's experiences and interaction within a place. The spatial characteristics of an SES are critical to the resilience of the system (Cumming 2011a), thus it is important to integrate the concepts of place and space within the scope of SES research.

A comprehensive modern discussion of the concepts of space and place was initiated by Tuan $(1974,1977)$. He described the scope of individual experiences in differentiating space and place, and further explained that an individual's scope of experience is the arena in which the individual learns from her/his encounters and is influenced by her/his senses. The concept of place is related to the individual's perceptions and interactions within her/his environment, the resulting feeling of well-being, and the cognition or comprehension of sustainability of the space. Experience is thus the starting point for recognizing sustainability-related issues and attempting to manage the resilience of the individual's self and place or connected environment. Our study draws attention to the role of autobiographical memory with such experiences in 
a certain place in enhancing the understanding of socialecological contexts of an SES.

Phenomenologists have given much attention to place attachment in relation to individual environmental attitudes and behaviors (Tuan 1974, Relph 1976, Buttimer and Seamon 2015). Their rich and varied analyses of place attachment often emphasize subjective experiences within cultural and historical contexts (Low and Altman 1992). Although they use various terms to refer to place attachment or person-place bonding relationships, such as "topophilia" (Tuan 1974), our study uses the term "place attachment" to refer to the broadest notion of the person-place bond. Our focus is on the individual's cognitive functions, including knowledge, understanding, and beliefs about diverse aspects of the environment, which have been largely neglected in the field of social science (Low and Altman 1992).

Therefore, SEM comprises of three aspects (Fig. 1): memory carriers as the primary agents of SEM (person); management practices based on local observations and experiential knowledge (practice); and physical sites in which the agents of SEM experience and practice ecosystem management (place). Furthermore, the dynamic feedback between person and practice, person and place, and practice and place, manifests in three related ways: (1) development of an individual's ecoliteracy, that is, knowledge, skills, and attitudes in relation to ecosystem management; (2) development of place attachment based on bonds between individuals and places; and (3) development of identity of a place through ecosystem management practices.

\section{CASE STUDY: AUTOBIOGRAPHICAL SOCIAL- ECOLOGICAL MEMORY IN PARK WAN-SUH'S NOVEL}

In the original Korean version of her English translated novel Who Ate Up All the Shinga?, Park Wan-suh (2009) acknowledges that she wrote her novel by completely relying on her memory. From the onset, Park presents a vivid description of her life in a Korean traditional village where she was born and spent her early childhood. Park's descriptions capture the essence of ecological values and ecosystem services of the Korean traditional village landscape (KTVL) that has largely been the social-ecological background for studies of Korean traditional ecological knowledge (KTEK).

Before the impact of wide-scale industrialization and globalization on the Korean peninsula, Korea was primarily a natural resource-dependent society. The KTVL is a representative unit of a natural resource-dependent community generally characterized as an agro-forestry-based human settlement located within a watershed according to age-old geomantic principles and practices that helped the community meet important ecological, economic, cultural, and spiritual functions (Koh et al. 2010, Lee 2017).

The KTVL provides a suitable setting for developing and understanding measures of resilience for four reasons. First, Korean traditional villages are geographically bounded within watersheds and identifiable as integrated systems of humans and nature. The KTVL residents traditionally preferred to reside in the upper reaches of a watershed surrounded by mountainous areas, because the watershed's boundaries would prevent excess wind and water deficiency, particularly during the dry Korean spring season when seeding of crop species and rice transplanting must be done (Lee 2017). At the scale of a watershed, critical slow variables, such as amount of soil organic matter and alkalinity, tend to be buffered by stabilizing feedbacks that protect the area from fast variables such as variation in rainfall during the growing season and clean water (Carpenter and Turner 2000, Olsson and Folke 2001, Chapin et al. 2009, Walker et al. 2012). Second, in rural areas, many ecological and social processes, such as hydrology and resource use, still follow annual cycles, providing opportunity for temporal change analysis. Third, Korea's remaining traditional villages are often subject to disturbances and shocks, such as floods, droughts, and social changes driven by urbanization and globalization. Fourth, traditional villages often exhibit a specific landscape configuration adapted to local conditions and include a characteristic landscape element known as a traditional village grove, which has played an important role in strengthening the resilience of the community (Koh et al. 2010).

\section{Approach}

Because the purpose of our study is to explore SEM in an autobiographical account and discuss its contribution to comprehending traditional social-ecological contexts, we focused on finding evidence of ecoliteracy, place attachment, and identity of a place, particularly in relation to KTVL. To this end, we analyzed the social-ecological contents of Park's (2009) novel within TEK perspectives by using computer-assisted qualitative data analysis software, MAXQDA 12 (VERBI Software, Berlin, Germany). Among the three well-known approaches of content analysis - conventional, directed, or summative - we chose the directed content analysis approach, which begins with other key concepts or theories as guidance for initial codes (Hsieh and Shannon 2005). In our study, we borrowed key concepts of TEK for our initial coding process.

Several scholars describe TEK as an evolving knowledge system that is informed by the long-term feedback relationships between traditional or local communities and the ecological systems they depend on (Berkes et al. 2000, Armitage 2003, Folke 2004, Berkes 2008). Few scholars, however, have examined the TEK reflected in historical literature and art. History and culture are veritable means of TEK's transmission (Berkes 2008), and it is purposeful within TEK studies to examine historical literature and art that contain knowledge and practices of ecosystem management. Ecologists have an increasing role in leading and informing multilevel societal efforts to enhance public ecoliteracy (Jordan et al. 2009, Cardelús and Middendorf 2013), and literature or art can indeed serve them as a public-friendly means for improving the understanding of TEK or SEM integral to an SES.

In general, four levels of ecological knowledge are recognized in studies of TEK and ecoliteracy (Berkes et al. 2000, Pilgrim et al. 2007, Berkes 2008): (1) local knowledge of land, plants, and animals; (2) land and resource management systems; (3) social institutions; and (4) cosmology or worldview. We adopted these four levels of TEK to classify the texts collected for the directed content analysis (Potter and Levine-Donnerstein 1999, Hsieh and Shannon 2005). We used the methodology suggested by Hsieh and Shannon (2005): we analyzed the texts and highlighted all content that, on the first impression, seemed to represent SEM in the context of TEK. Then, we categorized all the highlighted passages as per the four levels of TEK. The remaining highlighted passages that were not categorized were then given a new category: place attachment. 
There are two reasons for choosing the four levels of TEK as the initial categorization scheme in finding evidence of ecoliteracy, place attachment, and identity of a place. First, the four levels of TEK represent the ecoliteracy of people in resource-dependent communities (Pilgrim et al. 2007). Second, it is highly plausible that some elements of TEK are strongly associated with place attachment and the identity of a place. Place attachment often leads to the development of personal notions on how much or why the person values a certain environment, thus influencing the person's worldview (Wynveen et al. 2014). Furthermore, a physical place, such as a landscape, is the result of human engagement with nature (Johnson and Hunn 2010), which is influenced by landscape knowledge, human practices, and cosmological beliefs of a given system (Toledo 1992). Thus, we hypothesize that TEK, particularly the second level of TEK, determines the identity of a place, or spatial characteristics, and by employing the four levels of TEK, we can present aspects of ecoliteracy, place attachment, and the identity of a given KTVL.

\section{Findings}

Through our analysis, we found that the novel's content relates to every level of TEK. As hypothesized, TEK-related content represented the author's ecoliteracy, place attachment to her hometown, and the characteristics of the KTVL where she was born and grew up (Fig. 2). In particular, most content is related to the second level of TEK, land and resource management, through the author's descriptions of the spatial identity of her hometown, while the content related to the fourth level, worldview, characterizes her place attachment. There is also some content that does not belong to the levels of TEK, but was categorized as content related to place attachment.

Fig. 2. Summary of Korea's traditional ecological knowledge (TEK) based on the analysis of Park's (2009) autobiographical novel (adapted from Berkes 2008).

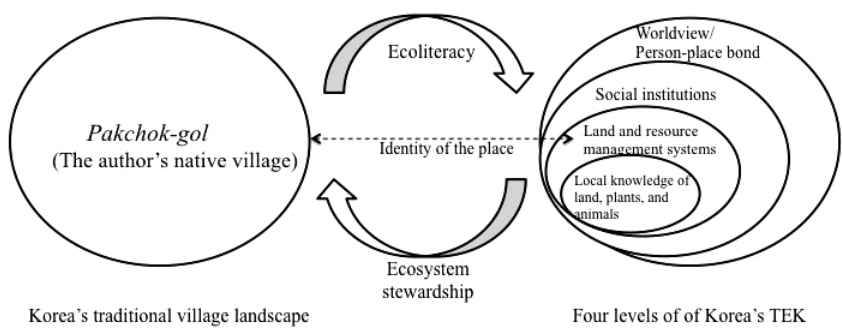

Through the 12 chapters of her novel, the author vividly describes her childhood in every new environment she moves into, including her home village, Seoul, and public school, during the most turbulent period in Korea's modern history, which was marked by the Japanese colonization and the Korean War. The author begins with her childhood in her village, and compares what she learned from nature with what she learns in Seoul and public school. We carefully examined the categorized contents, and selected excerpts that contrast the author's experience both in the countryside and Seoul because these were found to deliver the significance of SEM.

First level of TEK: local knowledge of land, plants, and animals The title of Park's (2009) novel mentions a plant species, shinga in Korean, or Aconogonon alpinum (All.) Schur, and she mentions more than 20 kinds of local plants that she remembers from her childhood, including mulberry, bush clover, peony, chrysanthemum, forsythia, ground cherry, cheery tree, wild apricot, pear, strawberry, pungent scallion, lily, pines, chestnuts, alder, and zelkova. For a child in a small agro-forestry dependent village, it seems easy to recognize many plants, as illustrated in an excerpt below from Park's novel:

Children aren't any different. We had our three meals a day at home, but we were always on the lookout for snacks and coming up with ways to while away our time in the mountains and fields. There would be new sprouts galore to choose from-sweetgrass, wild rosebuds, mountain berries, arrowroot, bindweed root, chestnuts, acorns, and shinga. When we picked them, we were able to satisfy our creeping hunger and had the chance to please the grownups, as when we collected mountains herbs and mushrooms. Some of them, like "jar mushrooms" and "bush clover mushrooms," sprouted so fast that you could almost imagine a finger pushing them up from the ground when you turned your back (p. 16).

Because she was born and grew up in a place with diversity where she learned within nature and was never bored, everything looked strange and artificial when she moved to a shantytown in Seoul, where she could not find natural spaces and had difficulty making friends as illustrated in Chapter Four, titled "friendless child":

What I missed even more than my friends, though, were the hills of the countryside. I found Seoul's hills odd, with their barren ground exposed between sparse, tiredlooking trees, as though we were in the grip of a drought. To me, mountains, like fields, meant a constant supply of treats, and I knew well that the tasty snacks were found in the shade, rather than high up in the trees. Our hills back home had pines, but there were also thick with deciduous trees like chestnut, alder, zelkova, and various oaks. When autumn came around, piles of fallen leaves were heaped roof-high in every yard for use as winter fuel (p. 63).

The bare, enervated ridge in Seoul made me think instead of a dying old man. To relieve my loneliness on my daily climb, I dwelled in memories and found excuses to look down on my peers in Seoul. They could never know the translucent blue of the dayflower's petals or the beautiful music that lurked within its leaves. Or if you carefully scratched away the thick, gleaming flesh, you'd discover veins that were thinner and more delicate than summer silk. Or the sound the veins gave off when you vibrated them against your lips. I could barely get a noise to come out, but some kids could make beautiful, plaintive melodies (p. 64).

The excerpts above signify that the narrator's hometown was a place where she could learn within and about nature with all her senses. Her knowledge of plants and the landscape was not the result of learning by rote, but the result of sensate experience within nature. In this regard, the author mentions how she "thirsted after real mountains and a spring worthy of the name" (p. 62) when she learned a string of Japanese sentences about 
spring at school, implying that the KTVL where she lived was quite different from her new home in Seoul. It also appears that there was a weak relationship between the hills and residents of Seoul, as she mentions the existence of public officer "watchmen" in the hills of Seoul.

\section{Second level of TEK: land and resource management systems} (1) Land management systems

The content related to land management systems not only indicates the author's knowledge of her village, but also reveals the identity of a KTVL characterized by a complex arrangement of diverse landscape components with specific functions.

First, the landscape components that she mentions include low and gently sloping hills, vast fields, small streams, many brooks, outhouses, paddy fields, vegetable patches, grasses, kitchen gardens, houses with thatched roofs, gardens, mountains, forests or groves at the entrance of the village, many pools called as "bonus wells," and a well. Although these elements sound common, with apparently no special meaning, they are valuable refuges for various living organisms that enrich the village's biodiversity. Park's description of the bonus well, a unique component of the village landscape, reads as follows:

When these streams met rice paddies, they often formed pools. We called these pools "bonus wells." This was to mark them off from the ones from which we drew water. In retrospect, they were more like small reservoirs (p. 3).

The author's descriptions of the various landscape elements in her village also provide insights into the biodiversity functions and services of the KTVL system. Aside from the mountains and forests that surround the village, even the undrinkable well named as "bonus well" is recognized as an important refuge of biodiversity in agricultural areas in Korea (Lee 2004). In a chapter of another book titled The Hill I Lost, Park (1993) elucidates the location, size, and biodiversity of a bonus well as follows:

There used to be a bonus well within the paddy fields. This bonus well was bigger than the wells dug at the edge of the fields and smaller than a regular pond, and to a child, it was a shaded place of unknown depth.... The bonus well was a messy place with all kinds of water plants and water insects. Tadpoles hatched in the bonus well, and it was probably because of the bonus well that the area swarmed with mosquito larvae in the summer. Diving beetles, water striders, giant water bugs, water scorpions, and water scavenger beetles also thrived among the marshy plants (Park 1993, as cited in Lee 2004:557-558).

It is widely accepted that heterogeneous landscapes enhance local biodiversity and thereby the resilience of the landscape (Fischer et al. 2006). The bonus well can also be understood as a form of adaptive landscape management to deal with insufficient rainfall during the dry season in Korea. Thanks to the traditional ecological management systems, the author remembers that the fields of her village "hardly ever yielded a bad crop" (Park 2009:3).

Also, in the Korean version of her novel, Park (2009) refers to dong-gu two times, which is translated as "the hill" (p. 6) and "the village entrance" (p. 8) in the English version of her novel. The word dong-gu represents the concept of watershed because the term dong 洞 an administrative unit for villages in Korea, means "same water source" (Lee 2004), and the term gu refers to "an entrance." The term dong-gu is often replaced with another Korean term su-gu meaning "water entrance" (Lee 2004), indicating that the entrance of the KTVL is where the village water discharges. Dong-gu is translated as "the hill" in the English version of the Park's (2009) novel, presumably because it is related with the Korean traditional landscape management practice of cultivating a grove at the entrance of the village to slow the discharge of the exiting water (Lee 2017). Such a grove is called sugu-magi, maeulsoop, or bibosoop and its ecological and social functions have been well studied by social-ecological researchers (e.g., Lee et al. 2007, Koh et al. 2010, Joo and Park 2012, Yu et al. 2014, Lee and Krasny 2015).

Second, Park (2009) describes a small village that represents a typical KTVL. In terms of a village boundary, she explains that the village nestled "between low, gently sloping hills that were free of boulders" (p. 3). The Korean name for her village is "pakchokgol," which literally means "valley of the Park clan." Thus, her village landscape was the valley within a watershed bounded by gentle mountain ridges. Often, Korean traditional villages are located in valley landscapes within watersheds (Koh et al. 2010), making many villages resemble each other in their boundaries and landscape arrangements, as reflected in the novel:
We crossed fields and climbed hills. Everywhere that a field and a hill met was a village, some bigger than Pakchok Hamlet and others smaller, but the way they sat in their surroundings was familiar, as was the way houses looked. I had accepted villages as part of a larger natural order (p. 31).

Such a landscape arrangement, located within a watershed and surrounded on three sides by hills or mountains, has long been considered an ideal arrangement for settlement in Korea because it allows the residents to adequately access water, arable land, fuelwood, and edible plants in the mountains (Lee 2017). For example, Park (2009) remembers the easy access to water in her village, when she finds that her family needs to buy water from water sellers in Seoul:

In Pakchok Hamlet, a brook ran down from the forsythia shrubs and through the vegetable patch in our yard. It never flooded or dried up, so for the most part it either gurgled cheerfully or whispered almost inaudibly, but our main room faced directly onto it, and during the rainy season it jabbered at us (p. 45).
The brook was where we washed our clothes, peeled our potatoes and yams, rinsed our greens, and of course, washed our hands on the way back from the outhouse. That any of this might be unsanitary never even entered our heads: we had a never-ending supply of fresh water (p. 46).

Furthermore, this ideal location for a KTVL is also described in the Sangtaekji, a historical Korean reference book with recommendations on choosing settlements. In Table 1, we show the comparative similarities between excerpts from Park's (2009) novel and Sangtaekji, with regard to descriptions of landscape components and arrangements in a KTVL. It is evident that the 
Table 1. Comparisons of excerpts from Park's 2009 novel Who Ate Up All the Shinga? and Sangtaekji, a historical Korean reference book, showing similarities in descriptions of landscape components and arrangements in a Korea's traditional village landscape.

\begin{tabular}{ll}
\hline \hline Excerpt from Who Ate Up All the Shinga? (Park 2009) & Excerpt from Sangtaekji (translated into modern Korean by Park 2004) \\
\hline $\begin{array}{l}\text { Our village was nestled between low, gently sloping hills that were free of } \\
\text { boulders and commanded an unobstructed view over vast fields. A small } \\
\text { river snaked through the broad plains in the center, and brooks were } \\
\text { everywhere. ... Even a trip to the outhouse for us meant crossing a little } \\
\text { stream. }\end{array}$ & $\begin{array}{l}\text { There are certain landscape features to be observed when selecting a } \\
\text { residential site. With regard to the mountains that surround a residential } \\
\text { site, they should not rise steeply, no matter how high they are; while they } \\
\text { should also not be concave like a grave, no matter how low they are. }\end{array}$ \\
$\begin{array}{l}\text { Even when we walked and walked through the fields, we never reached one } \\
\text { [village]. Only by climbing over the hill behind us could we reach a } \\
\text { neighboring village, and there was nothing especially remarkable to me } \\
\text { about it. Houses, flanked by vegetable patches, were nestled at the foot of }\end{array}$ & $\begin{array}{l}\text { These are preferred: hills with gentle slopes closely arranged at one place; } \\
\text { perennially flowing streams. The homes should have vegetable gardens } \\
\text { a hill, and broad fields billowed like a skirt in the front of the village. I } \\
\text { assumed everyone lived similarly. }\end{array}$ \\
$\begin{array}{l}\text { stream for fishing and irrigation should flow beside the fields. } \\
\text { Furthermore, over the stream, there should be mountains, shaped like a } \\
\text { writing-brush rack, or a coronet braid, or a rising cloud so as to form an } \\
\text { enjoyable scenery. }\end{array}$ \\
\hline
\end{tabular}

spatial arrangement of landscape components and interactions constitute the spatial identity of KTVL.

(2) Resource management systems

Park (2009) devotes a significant part of her first chapter to humor her readers with descriptions of the village outhouse, the traditional toilet detached from the residential building, from the perspective of a small girl. An outhouse has the important ecological function of recycling nutrients, besides having the public health benefits of a sanitary method of fecal waste management. The description of the outhouse illustrates several aspects of KTEK and its application in the KTVL. First, to facilitate the collection, transport, and effective use of human excreta, toilets in the KTVL were usually located close to vegetable patches. Park (2009) also describes this location as follows:

...our outhouse lay at the edge of our vegetable patch. To get to it, you had to climb down three stone ledges, traverse the outer yard, cross under the surrounding mulberry trees, and ford a small stream (p. 8).

Second, outhouses were built and managed to quickly convert excreta into fertilizer by using ash. Here, by pointing to the misperceptions among urban children nowadays about traditional lavatories, Park (2009) discusses an important aspect of this nutrient recycling:

Children nowadays, what with their phobia about countryside outhouses, would probably gag at that tale, but in fact the outhouses where I grew up were clean enough to eat porridge in. They were very roomy, sometimes as big as three or four kan, with a wooden frame in one corner where adults would take care of their business. Kids just squatted on the dirt floor. This area resembled a shed, and its floor was slanted to allow turds to roll downward, not into a deep pit, but into a section where ash from the kitchen furnace was dumped. In outhouses, people kept handy a long stick with a rectangular board attached, which children also used to sweep their droppings into the ash (this is why a gangly person is sometimes called a "shit stick") (pp. 13-14).

Grown-ups, for their part, swept the outhouse ground morning and evening, leaving behind clear broom marks.
Back then, excrement was used, together with compost, for fertilizer. The population was small relative to the amount of cultivated land, so this night soil was always in short supply. Disposing of the ash in the outhouse covered the feces and increased its value by bulking it up (p. 14).

Third, Park (2009) describes how villagers, even children, routinely participated in the management of the outhouses, which instilled a sense of pride among the villagers:

The most important thing was to deposit plentiful wellformed turds in the outhouse. We knew there was nothing shameful in shit, because it went back to the earth, helping cucumbers and pumpkins grow in abundance and making watermelons and melons sweet. We got not only to savor the instinctive pleasure of excretion, but to feel pride in producing something valuable (p. 15).

This implies that all villagers regardless of age appreciated participating in resource management. In this way, KTVL residents developed their management practices and their identity of KTVL through intricate human-nature relationships within the village boundary. Effective management practices are also related to traditional community governance.

Third level of TEK: social institutions

Park (2009) mentions that the village had fewer than 20 households, and the Pakchok Hamlet was named after the Pak (Park) clan. Two families were from the Pak clan and 16 or 17 families were from the Hong clan, indicating that kinship played a central role in governing the village community. The author assumes that the village took the name because the Paks were yangban (aristocrats), while the Hongs were commoners. However, being a remote, resource-dependent village, "the division didn't correspond to a split between landowners and tenant farmers" (p. 3). Rather, the author describes the villagers enjoyed economic equality:

No one family had a monopoly over the fields; no family had to struggle along without any. They were all diligent independent farmers and had no need to worry about food at any point in the year. Growing up in a community like this until I was seven, I didn't have the opportunity to 
learn that there were separate classes of people known as "rich" and "poor" in this world (p. 3).

In the novel, the author presents a number of divisions that she found in Seoul including the division between rich and poor, between the center and the periphery, the ruling and the ruled, and the right and the left. Later when the author becomes aware of different social-political ideologies, it is presumably her experience in her village that influences her to perceive the economic equality in communism as reasonable. In addition, there are passages that give a glimpse of villagers respecting traditional values and helping one another when great and small events occur:

\begin{abstract}
Not only residents of Pakchok Hamlet, but people from surrounding villagers arrived as well, accompanied by their children, and slept and ate in the bereaved household. Everyone envied the deceased's good fortune, because we were able to carry out the funeral rites generously despite being in the throes of a national crisis. This was all thanks to Elder Uncle, who cared for Grandfather until his death and at the time was the township's director of general affairs (p. 114).

On the day of burial, a long line of people with mourning flags snaked after the bier from our house to the hill where Grandfather would be laid to rest. The ancestral tombs were not far away. Both the bier itself and the entire scene struck me as an exquisite spectacle, the likes of which you almost never got to see in Seoul (p. 115).
\end{abstract}

Rapid social changes triggered by the Japanese colonization and frequent wars in Korea, however, made it difficult to continue living in the same way. As the author remembers, the men were forcefully drafted into the military and the women were taken as comfort women to Japanese rape camps. She even witnessed village girls getting married at the age of 13 and 14 to avoid to be taken. However, it was trust and reciprocity that helped the Pak clan:

\begin{abstract}
Our fellow villagers were very sympathetic and cooperative. They helped to make our house livable once more, helping us fix broken doors and furnishings. All this was before partisan politics - the Democratic Youth League, the self-defense corps, leftists-distorted people's inherent good-heartedness (p. 161).
\end{abstract}

Fourth level of TEK: cosmology or worldview

(1) "Our village"

Throughout her novel, Park (2009) frequently uses the pronoun "our." When she speaks of her village, she always says "our village" and "our villagers." In the Korean language, it is common to say "our place" instead of "my place" when referring to one's house. Consequently, when one refers to one's village, as in Park's (2009) novel, the Korean people often say woori dongne, which can be literally translated as "the inner side of our village." Unfortunately, "our village" and the pronoun "our" have not been used much in the English translated version of the novel.

The Korean phrase woori dongne has two implications for the worldview of the native users of this phrase. First, by using woori meaning "our," they indicate that the village is a shared place, probably also including nonhuman living organisms. Second, by using dongne to mean "village," they imply a spatial boundary for their shared living space. Traditionally, Koreans preferred to manage their village landscapes as closed systems, for several useful purposes. By cultivating trees or a grove at the front of a village, or settling in an area with a narrow entrance, they purposely made their village opaque to the outside. With a specific spatial boundary in mind, villagers could innovate and optimize practices for sustainable natural resource management, thereby reducing their ecological footprint. This also reduced scale mismatches in the local SES because the villagers managed social patterns and processes based on their understanding of ecological patterns and processes within the defined village landscape.

(2) Nature as a living entity and human-in-nature system

Although Park's (2009) childhood village was spatially small, the village landscape was a dynamic place replete with fulfilling human-nature interactions, thus reflecting the deep bond between the author and the place. An excerpt from her insightful words reads as follows:
We were part of nature, and because nature is alive, changing, in motion, not resting a single moment, we had no time to be bored. No matter how hard farmers work - scattering seed and tending their crops as they sprout, grow tendrils, bloom, and bear fruit - they can never gain a step. Nature has its own busy rhythms (p. 16).

This rich experience in nature led to the development of attachment to not just the village but the earth. For example, the author's mother transformed their grey vacant space into a flower garden when they first moved to their own house in Seoul. Also, when the author's family had a chance to move to a house at the school where the author's brother worked as a teacher, both the author and her mother were overjoyed to see space available for a vegetable garden at the house:

\begin{abstract}
Eventually I turned around again and discovered that she was playing with the dirt, like a child. When her eyes met mine, the humble, bashful smile she flashed made me think of a potato flower. "I want to move here right away. The soil is as fertile as can be. Imagine, letting such good earth go to waste!" (p. 207)

My pulse quickened as I imagined coming home on weekends and dashing toward Mother, arms raised high, while she weeded, I pictured her amid waving leaves of peppers, lettuce, cucumbers, squash, sesame, and all sorts of greens. The vegetable patch meant that I wouldn't just be going home, but home to the countryside (p. 208).
\end{abstract}

Other findings in relation to place attachment

Our findings reveal that apart from elements in relation to the four levels of TEK, there are contents showing place attachment, particularly in relation to the author's longing for the countryside:

Tomorrow, I'm going to get to climb up hills and walk through fields and splash in streams. I'm going to get to breathe in air that's got the smell of grass and wildflowers 
and soil. Just imagining this brought me an elation reminiscent of stepping at dawn in early summer onto the dewy, green path, and its carpet of dayflowers. I wasn't just homesick. I had a ravenous hunger, and it was about to be satisfied. For the first time, I felt a sense of superiority over my peers in Seoul (p. 81).

I wandered the hills and fields as if in a trance, friendless. Once I went out with little cousins in tow and gathered a heap of mountain herbs. Nothing made me feel more at peace than going out with a small basket at my side, like the village women. I thought that the basket suited me better than a book bag and that no matter how hard Mother pushed me, I simply wasn't cut out for study. Wasting the care and hope Mother had lavished on me would be a shame, but I had no intention of returning to school (p. 150).

The excerpts above indicate that the author's experiences of living in Seoul and visiting the countryside once or twice a year triggered the process of developing her attachment to the place. With her attachment to her village environment, the author kept visiting her village home despite the tension between her Auntie and Grandmother, and the growing animosity between the Soviets and the Americans: her village environment "offered [her] a physical and spiritual lifeline" (p. 176). As the reader advances through her novel, it becomes clear that it was her fulfilling ecological interactions in her hometown that formed her artistic and resilient spirit with which she withstood the increasing social difficulties of her youth.

\section{DISCUSSION}

Our analysis of Park's (2009) autobiographical novel reveals that, although Park may not have intended to delve per se into the social-ecological dimensions of her childhood village, she offers valuable descriptions of the TEK-related values in her village based on her SEM, particularly when contrasting her experiences in Seoul. Park's (2009) descriptions in relation to the four levels of TEK are evidence of her ecoliteracy, place attachment, and the identity of KTVL.

First, the author's SEM in relation to the first level of TEK was the result of her sensate experiences within nature as a child. Psychological studies often focus on autobiographical memory for identifying a general period in individual or human development (Nelson 1993, Schuman and Corning 2014). For instance, Schuman and Corning (2014) found that a reminiscence bump for personal memories tends to be located at a younger age, even though this bump can extend from as young as five years of age to the late $20 \mathrm{~s}$. This reminiscence bump signifies the early access to natural environments wherein a child can experience the interconnectedness of humans and nature. The meanings of experiences at different life stages in relation to environment are also important in the research on place attachment (Low and Altman 1992). In case of Park's novel, the author's childhood experience and her TEK allowed her to discover unsustainable aspects of life in Seoul such as the absence of biodiversity in the hills, the urban children's disconnectedness to nature, water problems, and unsanitary management of human feces, which also deepened her emotional bond with her native village. This verifies our earlier discussion of the importance of an individual's experience in recognizing sustainability-related issues.
Second, in the findings of this study, excerpts from Park's (2009) novel and the Sangtaekji containing the landscape components and arrangements of KTVL are presented. When taking Park's novel as an example of SEM in an autobiographical framework, and the Sangtaekji as an example of SEM in a historical memory framework, the similarities between the two sources show that communal landscape management practices have prevailed for generations in Korea's traditional villages. This has not only contributed to the conservation of heterogeneous landscape components and biodiversity in Korean rural areas, but also allowed the encapsulation of SEM in both autobiographical and historical frameworks. The landscape practices and relevant knowledge in KTVL have been transmitted through the narratives of individuals and through the preservation of the physical landscape.

Therefore, the findings in relation to the second level of TEK represent a common identity of KTVL as a social-ecological landscape with distinctive spatial and cultural characteristics. Whereas the various living organisms the author describes may differ from those of other Korean traditional villages, the overall configuration of her village landscape and its components are reminiscent of traditional native villages for many Koreans. The KTVL within a watershed may also be seen as representative of a Korean traditional ecosystem-like concept, similar to other traditional societies in previous literature (Berkes et al. 1994, 1998). The author's vivid descriptions of her native village and of her feelings associated with her childhood spent in the KTVL are possibly two of the most widely appreciated facets of her novel that have kept it on the best-seller list in Korea throughout the last decade.

When the author compares her verdant native village with the bare hills and mountains in Seoul, she appreciates the ecological diversity she observed in her village. Folke et al. (2003) emphasize diversity as a key feature of the ability of an SES to persist in the face of change. In an SES, diversity can be understood as an insurance benefitting the SES in the phase of reorganization and renewal because the presence of diverse species with overlapping functions and memory reservoirs of diverse knowledge and practices are the results of past experience and accumulated information to changes (Folke et al. 2003). Therefore, the loss of the KTVL is the loss of not only the shinga, as the title of Park's novel implies, but also of the diversity, sensibility, and creativity inherent to a KTVL, which informs individuals with a comprehensive understanding of an SES.

Third, the villagers often collectively participated in managing the natural resources in the author's native village. The inclusive management of village resources, community trust, and reciprocity built upon kinship are indications of social capital that influence environmental outcomes and adaptive capacity of an SES (Pretty and Ward 2001, Lockwood et al. 2015). Despite this social capital, however, the author witnesses the collapse of the village community because of the social strife caused by colonization and wars. Although some Korean traditional villages still maintain some traditional institutions such as management of forest commons (Yu et al. 2014), Park's memories of the social institutions in the KTVL system and of the social changes indicate how normative factors such as power and cultural values may affect institutional dynamics and human-environment relations 
(Cote and Nightingale 2012). In addition, they also imply how inexperienced shocks of great severity, such as wars, may affect local social-ecological systems.

Last, the humans-in-nature worldviews found in Park's (2009) novel are closely coupled with her attachment to her village. Such a worldview where humans are perceived as embedded within ecosystems has been commonly observed in TEK studies (Martin et al. 2010). Modern scientific research mostly focuses on the quantification of ecosystem services, whereas it should also holistically consider the cultural and spiritual values that inform individual worldviews, perceptions of nature, and place attachment that relate to the manner in which the SES adapts under disturbance. The spiritual, inspirational, and aesthetic aspects of nature are significant motivations for ecological conservation and sustainability (Chapin et al. 2009), and in this sense art compensates for the deficiency of scientific quantification, by delivering place-based values of an SES.

What are the implications of this discussion for advancing research in the usefulness of SEM in literary work for understanding SES resilience? Based on our analysis, we believe that the novel lays the groundwork for resilience thinking, besides being a valuable reservoir of SEM. Resilience thinking posits the concept of complexity and integrated human-environment systems as grounded worldviews (Folke et al. 2002, Berkes 2007). Thus, understanding the characteristics of change and the interaction between humans and nature is key to apprehending resilience theory (Allison and Hobbs 2004). Although scientific studies have focused on the concept of SES in analyzing social components of sustainability, much of the literature favors quantitative approaches (Stojanovic et al. 2016). We believe that literary works may fill the gap with their qualitative components by providing insightful narratives of social and ecological changes, as well as presenting alternative worldviews based on their connectedness to nature.

For example, the novel incites readers to reflect on what the Korean society has undergone in the early 20th century and the values lost in the modern society. Some readers of Park's (2009) novel may be curious why she devotes a large part of her childhood account to describe her native village. As the narrative advances, it becomes clearer that her SEM related to her village is linked to her identity and self-esteem. Also, her memories in the village can be understood as the memories within her reminiscence bump, which not only relate with a person's self-identity, but also inform the person's aspirations, attitudes, and beliefs (Conway et al. 2005). In this regard, the author often compares her observations of the period of colonization and the wars with her SEM from her native village, thus allowing the readership to discover why the Korean people had to leave the countryside and how the national ideology was divided.

Occasionally, the author and her mother show the use of SEM in Seoul, such as creating a garden, and these are one of few parts of the novel with no conflicts and divisions observed. It is known that SEM may also lead to maladaptive management practices because the social processes of memory are not intrinsically benevolent (Nykvist and von Heland 2014). However, the evidence in the novel implies that SEM may function as a source for self-organized efforts and healing in urban areas (Krasny and Tidball 2012). In this sense, the composition, context, and medium of an artist's work can offer relevant insights on the comprehension of natural resource knowledge and prevalent management practices shared within a certain population, particularly when the artistic work is based on the artists' real experiences as in the case of Park's (2009) novel. However, autobiographical memory is known to fade with time, unless it is periodically reinforced or brought to awareness through contact with others (Halbwachs 1992). This is why Park's (2009) narratives of her childhood memory may serve an even more important role in sustaining the SEM for other Korean people with similar memories in relation to KTVL.

In addition, Park's (2009) novel shows that the worldview where human and nature are perceived as an integrated system has long existed in Korean culture. This is important because the memory in relation to such a worldview may play a significant role in guiding social actors for innovative self-organization, particularly in the phase of reorganization and renewal in an SES. According to Halbwachs (1992), social groups tend to choose different memories to explain current issues and concerns, and leaders in society reconstruct the past by rationalizing what events are to be remembered or eliminated, and by rearranging the remembered events to conform to social narratives. Leaders of communities and policy makers therefore need to find methods to motivate more individuals to perform ecosystem and landscape stewardship practices by utilizing their SEM. Korean society has suffered from severe conflicts and divisions for several decades. By shifting cultural awareness of an attachment to nature and to a human-in-nature worldview, the novel invites the readership to reflect on man-made conflicts and divisions as well as its influence on a local SES.

Some researchers also describe the impacts of storytelling on the development of personal resilience (East et al. 2010). For individuals, chances to enhance adaptive capacity are promoted through engagement in various experiences accompanied by reflectivity, and a community with such competent individuals possibly has a higher adaptive capacity (Fazey et al. 2007). In addition, because many Korean agricultural villages exist as clanbased communities, artistic works that depict village landscapes can motivate appreciators of the art, especially those who live in urban areas, to contemplate their rural origins or visit their rural relatives.

It is important to employ combinations of various approaches to gain a robust understanding of social-ecological processes and interactions within an SES. Art has traditionally been and can be a comprehensive approach that engages the public in an interactive process of scientific research. Arts-based research or "arts for scholarship's sake" (Cahnmann-Taylor and Siegesmund 2013), for example, builds on the evidence that art has the potential to offer pathways to scientific research. Indeed, by analyzing an artistic work to present the dynamics of a local SES, a researcher can invite readers, and indeed other researchers, to a sense-making process, which is central for transforming circumstances into a comprehensible situation in words and serving as a springboard for identity formation and action (Weick et al. 2005). The analytical approach utilized in our study suggests the new functions of an autobiographical literary work in delivering and reinforcing SEM, and hopefully informs the interdisciplinary study of SEM across the fields of humanities, social sciences, and natural resources management. 
Responses to this article can be read online at:

http://www.ecologyandsociety.org/issues/responses. php/9284

\section{Acknowledgments:}

We would like to acknowledge the very useful and insightful suggestions and comments made by the subject editor and two anonymous reviewers. This work was supported by the Basic Science Research Program through the National Research Foundation of Korea, funded by the Ministry of Science, ICT, and Future Planning [grant number NRF-2015R1 A2A2A03007350].

\section{LITERATURE CITED}

Ahern, J. 2013. Urban landscape sustainability and resilience: the promise and challenges of integrating ecology with urban planning and design. Landscape Ecology 28:1203-1212. http://dx. doi.org/10.1007/s10980-012-9799-Z

Allison, H. E., and R. J. Hobbs. 2004. Resilience, adaptive capacity, and the "Lock-in Trap" of the Western Australian agricultural region. Ecology and Society 9(1):3. http://dx.doi. org/10.5751/es-00641-090103

Armitage, D. 2003. Traditional agroecological knowledge, adaptive management and the socio-politics of conservation in Central Sulawesi, Indonesia. Environmental Conservation 30:79-90. http://dx.doi.org/10.1017/S0376892903000079

Barthel, S., C. Folke, and J. Colding. 2010. Social-ecological memory in urban gardens: retaining the capacity for management of ecosystem services. Global Environmental Change 20:255-265. http://dx.doi.org/10.1016/j.gloenvcha.2010.01.001

Berkes, F. 2007. Understanding uncertainty and reducing vulnerability: lessons from resilience thinking. Natural Hazards 41:283-295. http://dx.doi.org/10.1007/s11069-006-9036-7

Berkes, F. 2008. Sacred ecology: traditional ecological knowledge and resource management. Second edition edition. Routledge, New York, New York, USA.

Berkes, F. 2009. Indigenous ways of knowing and the study of environmental change. Journal of the Royal Society of New Zealand 39:151-156. http://dx.doi.org/10.1080/03014220909510568

Berkes, F., J. Colding, and C. Folke. 2000. Rediscovery of traditional ecological knowledge as adaptive management. Ecological Applications 10:1251-1262. http://dx.doi.org/10.1890/1051-0761 (2000)010[1251:ROTEKA]2.0.CO;2

Berkes, F., J. Colding, and C. Folke. 2003. Navigating socialecological systems: building resilience for complexity and change. Cambridge University Press, Cambridge, UK. http://dx.doi. org/10.1017/cbo9780511541957

Berkes, F., C. Folke, and M. Gadgil. 1994. Traditional ecological knowledge, biodiversity, resilience and sustainability. Pages 269-287 in C. A. Perrings, K.-G. Mäler, C. Folke, C. S. Holling, and B.-O. Jansson, editors. Biodiversity conservation. Springer, Dordrecht, The Netherlands. http://dx.doi.org/10.1007/978-94-011-1006-8 15
Berkes, F., M. Kislalioglu, C. Folke, and M. Gadgil. 1998. Minireviews: exploring the basic ecological unit: ecosystem-like concepts in traditional societies. Ecosystems 1:409-415. http://dx. doi.org/10.1007/s100219900034

Berkes, F., and C. S. Seixas. 2005. Building resilience in lagoon social-ecological systems: a local-level perspective. Ecosystems 8:967-974. http://dx.doi.org/10.1007/s10021-005-0140-4

Berkes, F., and N. J. Turner. 2006. Knowledge, learning and the evolution of conservation practice for social-ecological system resilience. Human Ecology 34:479-494. http://dx.doi.org/10.1007/ s10745-006-9008-2

Brocchi, D. 2010. The cultural dimension of un/sustainability: delicate distinctions between societal survival and collapse. Pages 145-176 in S. Bergmann and D. Gerten, editors. Religion and dangerous environmental change: transdisciplinary perspectives on the ethics of climate and sustainability. Transaction Publishers, Piscataway, New Jersey, USA.

Buttimer, A., and D. Seamon, editors. 2015. The human experience of space and place. Routledge, New York, New York, USA.

Cahnmann-Taylor, M., and R. Siegesmund, editors. 2013. Artsbased research in education: foundations for practice. Routledge, New York, New York, USA.

Capra, F. 1996. The web of life: a new scientific understanding of living systems. Anchor Books, New York, New York, USA.

Cardelús, C., and G. Middendorf. 2013. Ecological literacy: the educational foundation necessary for informed public decision making. Frontiers in Ecology and the Environment 11:330-331. http://dx.doi.org/10.1890/1540-9295-11.6.330

Carpenter, S. R., and M. G. Turner. 2000. Hares and tortoises: interactions of fast and slow variables in ecosystems. Ecosystems 3:495-497. http://dx.doi.org/10.1007/s100210000043

Carpenter, S., B. Walker, J. M. Anderies, and N. Abel. 2001. From metaphor to measurement: resilience of what to what? Ecosystems 4:765-781. http://dx.doi.org/10.1007/s10021-001-0045-9

Chapin, F. S., G. P. Kofinas, C. Folke, and M. C. Chapin, editors. 2009. Principles of ecosystem stewardship: resilience-based natural resource management in a changing world. Springer Science \& Business Media, New York, New York, USA.

Conway, M. A., Q. Wang, K. Hanyu, and S. Haque. 2005. A crosscultural investigation of autobiographical memory: on the universality and cultural variation of the reminiscence bump. Journal of Cross-Cultural Psychology 36:739-749. http://dx.doi. org/10.1177/0022022105280512

Cote, M., and A. J. Nightingale. 2012. Resilience thinking meets social theory: situating social change in socio-ecological systems (SES) research. Progress in Human Geography 36:475-489. http:// dx.doi.org/10.1177/0309132511425708

Cumming, G. S. 2011a. Spatial resilience in social-ecological systems. Springer Science \& Business Media, New York, New York, USA. http://dx.doi.org/10.1007/978-94-007-0307-0

Cumming, G. S. 2011b. Spatial resilience: integrating landscape ecology, resilience, and sustainability. Landscape Ecology 26:899-909. http://dx.doi.org/10.1007/s10980-011-9623-1 
Cumming, G. S., C. R. Allen, N. C. Ban, D. Biggs, H. C. Biggs, D. H. M. Cumming, A. De Vos, G. Epstein, M. Etienne, K. Maciejewski, R. Mathevet, C. Moore, M. Nenadovic, and M. Schoon. 2015. Understanding protected area resilience: a multiscale, social-ecological approach. Ecological Applications 25:299-319. http://dx.doi.org/10.1890/13-2113.1

Davidson-Hunt, I., and F. Berkes. 2003. Learning as you journey: Anishinaabe perception of social-ecological environments and adaptive learning. Conservation Ecology 8(1):5. http://dx.doi. org/10.5751/es-00587-080105

East, L., D. Jackson, L. O'Brien, and K. Peters. 2010. Storytelling: an approach that can help to develop resilience. Nurse Researcher 17:17-25. http://dx.doi.org/10.7748/nr2010.04.17.3.17.c7742

Fazey, I., J. A. Fazey, J. Fischer, K. Sherren, J. Warren, R. F. Noss, and S. R. Dovers. 2007. Adaptive capacity and learning to learn as leverage for social-ecological resilience. Frontiers in Ecology and the Environment 5:375-380. http://dx.doi.org/10.1890/1540-9295 (2007)5[375:ACALTL]2.0.CO;2

Fischer, J., D. B. Lindenmayer, and A. D. Manning. 2006. Biodiversity, ecosystem function, and resilience: ten guiding principles for commodity production landscapes. Frontiers in Ecology and the Environment 4:80-86. http://dx.doi.org/10.1890/1540-9295 (2006)004[0080:BEFART]2.0.CO;2

Folke, C. 2004. Traditional knowledge in social-ecological systems. Ecology and Society 9(3):7. http://dx.doi.org/10.5751/ ES-01237-090307

Folke, C. 2006. Resilience: the emergence of a perspective for social-ecological systems analyses. Global Environmental Change 16:253-267. http://dx.doi.org/10.1016/j.gloenvcha.2006.04.002

Folke, C., S. Carpenter, T. Elmqvist, L. Gunderson, C. S. Holling, and B. Walker. 2002. Resilience and sustainable development: building adaptive capacity in a world of transformations. AMBIO: A Journal of the Human Environment 31:437-440. http:// dx.doi.org/10.1579/0044-7447-31.5.437

Folke, C., J. Colding, and F. Berkes. 2003. Synthesis: building resilience and adaptive capacity in social-ecological systems. Pages 352-387 in F. Berkes, J. Colding, and C. Folke, editors. Navigating social-ecological systems: building resilience for complexity and change. Cambridge University Press, Cambridge, UK. http://dx.doi.org/10.1017/CBO9780511541957.020

Folke, C., T. Hahn, P. Olsson, and J. Norberg. 2005. Adaptive governance of social-ecological systems. Annual Review of Environment and Resources 30:441-473. http://dx.doi.org/10.1146/ annurev.energy.30.050504.144511

Goleman, D., L. Bennett, and Z. Barlow. 2012. Ecoliterate: how educators are cultivating emotional, social, and ecological intelligence. John Wiley \& Sons, San Francisco, California, USA.

Halbwachs, M. 1992. On collective memory. Edited and translated by L. A. Coser. University of Chicago Press, Chicago, Illinois, USA.

Hsieh, H.-F., and S. E. Shannon. 2005. Three approaches to qualitative content analysis. Qualitative Health Research 15:1277-1288. http://dx.doi.org/10.1177/1049732305276687
Johnson, L. M., and E. S. Hunn, editors. 2010. Landscape ethnoecology: concepts of biotic and physical space. Berghahn Books, New York, New York, USA.

Joo, S., and S. Park. 2012. Identification of bird species and their prey using DNA barcode on feces from Korean traditional village groves and forests (maeulsoop). Animal Cells and Systems 16:488-497. http://dx.doi.org/10.1080/19768354.2012.720939

Jordan, R., F. Singer, J. Vaughan, and A. Berkowitz. 2009. What should every citizen know about ecology? Frontiers in Ecology and the Environment 7:495-500. http://dx.doi.org/10.1890/070113

Koh, I., S. Kim, and D. Lee. 2010. Effects of bibosoop plantation on wind speed, humidity, and evaporation in a traditional agricultural landscape of Korea: field measurements and modeling. Agriculture, Ecosystems \& Environment 135:294-303. http://dx.doi.org/10.1016/j.agee.2009.10.008

Krasny, M. E., and K. G. Tidball. 2012. Civic ecology: a pathway for Earth stewardship in cities. Frontiers in Ecology and the Environment 10:267-273. http://dx.doi.org/10.1890/110230

Lam, M. E. 2014. Building ecoliteracy with traditional ecological knowledge: do, listen, and learn. Frontiers in Ecology and the Environment 12:250-251. http://dx.doi.org/10.1890/1540-9295-12.4.250

Lee, D., editor. 2004. Korean traditional ecology. [In Korean with English translation available]. ScienceBooks, Seoul, Korea.

Lee, D. 2017. Geomantic practices of water acquisition and management during the Chosŏn dynasty. In H. Yoon, editor. P'ungsu: a study of geomancy in Korea, SUNY Press, Stony Brook, Albany, New York, USA, in press.

Lee, D., I. Koh, and C. R. Park. 2007. Ecosystem services of traditional village groves in Korea. [In Korean with English abstract.] Seoul National University Press, Seoul, Korea.

Lee, E., and M. E. Krasny. 2015. The role of social learning for social-ecological systems in Korean village groves restoration. Ecology and Society 20(1):42. http://dx.doi.org/10.5751/ ES-07289-200142

Lockwood, M., C. M. Raymond, E. Oczkowski, and M. Morrison. 2015. Measuring the dimensions of adaptive capacity: a psychometric approach. Ecology and Society 20(1):37. http:// dx.doi.org/10.5751/ES-07203-200137

Low, S. M., and I. Altman, editors. 1992. Place attachment. Springer, Boston, Massachusetts, USA. http://dx.doi. org/10.1007/978-1-4684-8753-4

Martin, J. F., E. D. Roy, S. A. W. Diemont, and B. G. Ferguson. 2010. Traditional ecological knowledge (TEK): ideas, inspiration, and designs for ecological engineering. Ecological Engineering 36:839-849. http://dx.doi.org/10.1016/j.ecoleng.2010.04.001

McBride, B. B., C. A. Brewer, A. R. Berkowitz, and W. T. Borrie. 2013. Environmental literacy, ecological literacy, ecoliteracy: What do we mean and how did we get here? Ecosphere 4(5):1-20. http://dx.doi.org/10.1890/ES13-00075.1

Morehouse, B. J., D. B. Ferguson, G. Owen, A. Browning-Aiken, P. Wong-Gonzalez, N. Pineda, and R. Varady. 2008. Science and socio-ecological resilience: examples from the Arizona-Sonora 
Border. Environmental Science \& Policy 11:272-284. http://dx.doi. org/10.1016/j.envsci.2007.07.007

Nelson, K. 1993. The psychological and social origins of autobiographical memory. Psychological Science 4:7-14. http:// dx.doi.org/10.1111/j.1467-9280.1993.tb00548.x

Nykvist, B., and J. von Heland. 2014. Social-ecological memory as a source of general and specified resilience. Ecology and Society 19(2):47. http://dx.doi.org/10.5751/ES-06167-190247

Olick, J. K., and J. Robbins. 1998. Social memory studies: from "collective memory" to the historical sociology of mnemonic practices. Annual Review of Sociology 24:105-140. http://dx.doi. org/10.1146/annurev.soc.24.1.105

Olsson, P., and C. Folke. 2001. Local ecological knowledge and institutional dynamics for ecosystem management: a study of Lake Racken Watershed, Sweden. Ecosystems 4:85-104. http://dx. doi.org/10.1007/s100210000061

Olsson, P., C. Folke, and F. Berkes. 2004. Adaptive comanagement for building resilience in social-ecological systems. Environmental Management 34:75-90. http://dx.doi.org/10.1007/s00267-003-0101-7

Park, K. 2004. Ecological considerations in developing a residential site. Pages 484-501 in D. Lee, editor. Korean traditional ecology. [In Korean with English translation available]. Science Books, Seoul, Korea.

Park, W.-S. 2009. Who ate up all the shinga?. Translated by Yu Young-nan and Stephen J. Epstein. Columbia University Press, New York, New York, USA.

Pilgrim, S., D. Smith, and J. Pretty. 2007. A cross-regional assessment of the factors affecting ecoliteracy: implications for policy and practice. Ecological Applications 17:1742-1751. http:// dx.doi.org/10.1890/06-1358.1

Potter, W. J., and D. Levine-Donnerstein. 1999. Rethinking validity and reliability in content analysis. Journal of Applied Communication Research 27(3):258-284. http://dx.doi. org/10.1080/00909889909365539

Pretty, J., and H. Ward. 2001. Social capital and the environment. World Development 29:209-227. http://dx.doi.org/10.1016/ S0305-750X(00)00098-X

Relph, E. 1976. Place and placelessness. Pion, London, UK.

Ruiz-Mallén, I., and E. Corbera. 2013. Community-based conservation and traditional ecological knowledge: implications for social-ecological resilience. Ecology and Society 18(4):12. http://dx.doi.org/10.5751/ES-05867-180412

Schuman, H., and A. Corning. 2014. Collective memory and autobiographical memory: similar but not the same. Memory Studies 7:146-160. http://dx.doi.org/10.1177/1750698013508196

Stojanovic, T., H. McNae, P. Tett, T. W. Potts, J. Reis, H. D. Smith, and I. Dillingham. 2016. The "social" aspect of social-ecological systems: a critique of analytical frameworks and findings from a multisite study of coastal sustainability. Ecology and Society 21 (3):15. http://dx.doi.org/10.5751/ES-08633-210315
Swidler, A., and J. Arditi. 1994. The new sociology of knowledge. Annual Review of Sociology 20:305-329. http://dx.doi. org/10.1146/annurev.so.20.080194.001513

Toledo, V. M. 1992. What is ethnoecology? Origins, scope and implications of a rising discipline. Etnoecológica 1:5-21.

Tuan, Y.-F. 1974. Topophilia: a study of environmental perception. Prentice-Hall, Englewood Cliffs, New Jersey, USA.

Tuan, Y.-F. 1977. Space and place: the perspective of experience. University of Minnesota Press, Minneapolis, Minnesota, USA.

Walker, B., S. Carpenter, J. Anderies, N. Abel, G. Cumming, M. Janssen, L. Lebel, J. Norberg, G. D. Peterson, and R. Pritchard. 2002. Resilience management in social-ecological systems: a working hypothesis for a participatory approach. Conservation Ecology 6(1):14. http://dx.doi.org/10.5751/es-00356-060114

Walker, B. H., S. R. Carpenter, J. Rockstrom, A.-S. Crépin, and G. D. Peterson. 2012. Drivers, "slow" variables, "fast" variables, shocks, and resilience. Ecology and Society 17(3):30. http://dx.doi. org/10.5751/ES-05063-170330

Walker, B., and D. Salt. 2012. Resilience practice: building capacity to absorb disturbance and maintain function. Island, Washington, D.C., USA. http://dx.doi.org/10.5822/978-1-61091-231-0

Weick, K. E., K. M. Sutcliffe, and D. Obstfeld. 2005. Organizing and the process of sensemaking. Organization Science 16:409-421. http://dx.doi.org/10.1287/orsc.1050.0133

Wynveen, C. J., G. T. Kyle, and S. G. Sutton. 2014. Environmental worldview, place attachment, and awareness of environmental impacts in a marine environment. Environment and Behavior 46:993-1017. http://dx.doi.org/10.1177/0013916513484325

Yu, D. J., J. M. Anderies, D. Lee, and I. Perez. 2014. Transformation of resource management institutions under globalization: the case of songgye community forests in South Korea. Ecology and Society 19(2):2. http://dx.doi.org/10.5751/ ES-06135-190202 